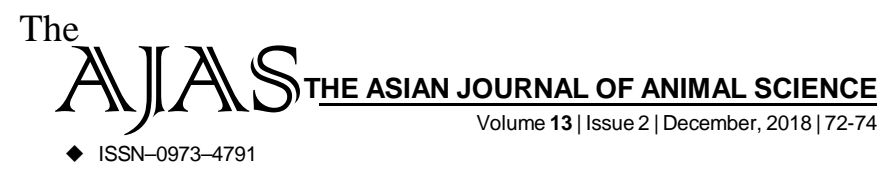

RESEARCH ARTICLE.

\title{
Study on skin thickness in crossbreed cattle
}

\section{P.J. Kapadnis and P.N. Thakur}

Author for Corresponding -

\section{P.N. Thakur}

Department of Veterinary Anatomy and Histology

College of Veterinary and Animal

Sciences, Parbhani (M.S.)

India
ABSTRACT......The skin of crossbreed cow (Deoni $x$ HF, $F_{1}$ generation) histologiocally showed three layers as epidermis, dermis and hypodermis. The epidermis consisted of four types of layers from outer to inner side as Stratum carneum, Stratum granulosum, Stratum spinosum and Stratum basale. The keratinocytes were found in the Stratum carneum, melanocytes and langerhans cells were found in Stratum spinosum and Stratum basale. The markels cells were round in basal layer of the epidermis in heifers.

KEY WORDS...... Skin, Thickness, Crossbreed cattle

HOW TO CITE THIS ARTICLE - Kapadnis, P.J. and Thakur, P.N. (2018). Study on skin thickness in crossbreed cattle. Asian J. Animal Sci., 13(2): 72-74. DOI : 10.15740/HAS/TAJAS/13.2/72-74. Copyright@2018: HindAgri-Horticultural Society.

ARTICLE CHRONICLE - Received : 27.08.2018; Revised : 12.11.2018; Accepted : 21.11.2018 